Doc. dr. Dušana

Findeisen

Filozofska fakulteta

$\checkmark$ Ljubljani

\title{
IZOBRAŽEVANJE STAREJŠIH
} ODRASLIH IN POMEN

\section{NJIHOVEGA IZOBRAŽEVANJA ZA NJIH SAME TER DRUŽBO}

\section{POVZETEK}

Avtorica predstavi pomen izobraževanja starejših odraslih za dejavno staranje v dolgem prehodnem obdobju, imenovanem »čas med delom, upokojitvijo in starostjo«. Ta koncept prehodnega obdobja, prehoda v starost, namreč danes nadomě̌ča starejši koncept pokoja. V tem času ljudje v poznejših letih življenja opravljajo plačano delo, se izobražujejo, se (občasno) vračajo na trg dela, delajo prostovoljno. Avtorica piše o prebivalstvenih spremembah in o pomenu izobraženosti vseh in vseh skupin starejših odraslih za soočanje s staranjem družbe. Dušana Findeisen zastane pri vprašanju značilnosti izobraževalnih programov za starejše odrasle, obravnava vrednote, nosilce in oblike izobraževanja starejših. Nazadnje opiše slovensko univerzo za tretje življenjsko obdobje kot konceptualno eno najbolj celostno domišljenih oblik in modelov izobraževanja ljudi $v$ poznejših letih življenja.

Ključne besede: starajoča se družba, izobraževanje odraslih, izobraževanje v poznejših letih življenja, dejavno staranje, tretje življenjsko obdobje, upokojitev, prebivalstvene spremembe, izobraževalni program, univerza za tretje življenjsko obdobje, izobraževalni model

$\mathrm{V}$

Sloveniji in v drugod je $\mathrm{v}$ zadnjih desetletjih prišlo do številnih družbenih prekinitev in posledično do vseh vrst neenakosti. Gre za ekonomsko neenakost, neenakost regij, urbano neenakost, neenakost spolov, neenakost po starosti. Sleherni družbeni sistem teži, da znova doseže ravnovesje, kadar se njegovo ravnovesje omaje, in tako bo k novemu ravnovesju težila tudi starajoča se družba. Radi jo tako imenujemo, toda ali jo razumemo, ali smo pripravljeni na to, da $\mathrm{v}$ tej družbi iščemo nova medsebojna razmerja, ali vemo, kaj nam je storiti? Kaj nam je storiti na področju izobraževanja in dejavnega staranja? Pa tudi, kdo so starejši odrasli, ali jih razumemo in poznamo, kakšno izobraževanje potrebujejo. Okrog teh in drugih vprašanj se vrti ta prispevek.

\section{STARANIE PREBIVALSTVA KOT NAJVEČJA PREBIVALSTVE- NA SPREMEMBA}

Nekaj povsem svežih podatkov iz evropskih projekcij: do leta 2060 se število evropskih prebivalcev ne bo spremenilo, 500 milijonov nas bo. Bomo pa precej starejši. V letu 2008 je bilo starejših nad 65 let 17 odstotkov navedenega števila, leta 2060 jih bo po projekcijah 30 odstotkov. Današnja srednja starost je 40 let, leta 2060 bo 48 let. Rodnost se zmanjšuje, 
priseljevanje tudi. Aktivnega prebivalstva bo manj, delovna sila se bo starala. Število starejših se bo najbolj povečalo v času od 2015 do 2030, ko bodo v pokoju generacije baby booma (glej Ageing Report 2009). Smo torej sredi staranja prebivalstva, ki se prvič v zgodovini pojavi v 20. stoletju. Znanstveniki ne znajo dobro razložiti, zakaj. Hipotez je veliko. Odgovora ni, a vse kaže na to, da je staranje prebivalstva nasledek dosežkov naše civilizacije (medicina, izobraženost, boljše življenjske okoliščine, pričakovana življenjska doba ob rojstvu, ki se povečuje za tri leta vsakih deset let) (glej Ageing Report 2009).

Današnje razmere v Sloveniji ilustrira naslednja razpredelnica.

Preglednica 1: Struktura prebivalstva, starega več kot 65 let, za leto 2006

\begin{tabular}{|c|c|c|c|}
\hline & & & 2006 \\
\hline & $65-69$ let & Spol - SKUPNO & 96.660 \\
\hline & 70-74 let & Spol - SKUPNO & 85.833 \\
\hline SLOVENIJA & $75-79$ let & Spol - SKUPNO & 69.113 \\
\hline & 80-84 let & Spol - SKUPNO & 43.781 \\
\hline & $85-89$ let & Spol - SKUPNO & 16.868 \\
\hline & $90+$ let & Spol - SKUPNO & 7.376 \\
\hline & & SKUPAJ vseh oseb & 319.631 \\
\hline SIOVENUA & $0-4$ let & Spol - SKUPNO & 91.011 \\
\hline SLUV EIVIJA & $5-9$ let & Spol - SKUPNO & 91.226 \\
\hline & 10-14 let & Spol - SKUPNO & 98.842 \\
\hline & & & 281.079 \\
\hline
\end{tabular}

Vir: Tomaž Banovec v zasebnem pismu leta 2008

Vzrok za staranje prebivalstva je lahko tudi manjša rodnost. Rodnost hitro pada v Italiji, najhitreje v pokrajini Ligurija. Pada v Grčiji, na severu Grčije. Otroci se ne rojevajo v dovolj velikem številu v vzhodni Nemčiji, kajti mlada dekleta se izseljujejo. Število prebivalcev se povečuje le v nekaterih pokrajinah, kjer je veliko priseljencev (v regijah Francije, Irske ipd.). Poljska se med novimi članicami Evropske unije stara najhitreje, Slovenija najpočasneje, a vendar se.

V študiji »Prebivalstvena prihodnost Evrope« Stephen Kroener s sodelavci (Stephen Kroener in drugi, 2008) popiše svoje ugotovitve o prebivalstvenih premikih $\mathrm{v}$ Evropi. Obravnava tudi Slovenijo. Dokaj prepričljivo. »Slovenija,« pravijo, $» j e$ po dohodku na prebivalca prehitela Portugalsko, staro članico Unije. Tako Slovenija ni več država z nizkimi stroški dela, takšna, ki lahko ponudi 'štiri milijone pridnih rok' za malo denarja. Ti časi so minili. Na kaj se tedaj Slovenija lahko opre, če želi biti konkurenčna?« Odgovor

S staranjem prebi-
valstva se prvič
zgodovini soočimo
$v 20$. stoletju.
je jasen: na znanost, razvoj, izobraženost vseh, poudarjam, vseh svojih ljudi. ${ }^{1}$ Za konkurenčnost Slovenije torej nista pomembni število otrok - to je stara paradigma - in število pridnih rok, marveč so potrebni dobro izobraženi in srečni mladi ljudje, ki se bodo znali vključiti v skupnost. Za Slovenijo je tako pomembna izobraženost vseh segmentov njenega prebivalstva, pomembna je funkcionalna pismenost prebivalstva, pomembne so dobro razvite računalniške spretnosti vseh prebivalcev, če želimo vstopiti v e-gospodarstvo, e-komunikacijo, imeti e-upravo, če želimo povečevati število inovacij, ki nastanejo le tam, kjer se ljudje pogovarjajo in so na tak ali drugačen način med seboj povezani. Pomembni so, razumljivo, izobraženi ter $v$ ekonomski in družbeni razvoj vključeni starejši.

Še pred petindvajsetimi leti je v industrijskih in socialističnih državah veljalo, da naj nekdo, ki je v pokoju, uživa zaslužen počitek. Alternativnih oblik življenja ni bilo. Danes pričakujemo - vsaj na deklarativni ravni je tako - da bo starejši delavec in upokojenec poskušal čim dlje ostati na trgu dela, vse bolj vemo, da je dobro, da se izobražuje, da dela prostovoljno ipd. Vprašanje pa je, ali smo se ob teh spoznanjih pripravljeni tudi spreminjati, vsi: politiki, delodajalci, strokovnjaki vseh vrst, ne nazadnje tudi izobraževalci odraslih? Kajti, vsi bolj ali manj razmišljamo iz preteklosti, ne iz sedanjosti ali celo prihodnosti. Starajoča se družba je tako obsežen pojav, da bo bistveno posegla $\mathrm{v}$ vse nas in vsa naša razmerja. 


\section{OD PREBIVALSTVENIH} SPREMEMB K IZOBRAŽEVANJU IN DEJAVNEMU STARANJU V POZNEJŠIH LETIH ŽIVLJENJA

Naslednje trditve je dobro imeti v mislih, ko bomo razmišljali o starajoči se družbi in o tem, kako se ob tem dejstvu spremeniti: (1) staranje prebivalstva je civilizacijski dosežek, ne spodrsljaj, pravi Ana Krajnc; ${ }^{2}$ (2) staranje prebivalstva nas ne ogroža; (3) staranje prebivalstva je priložnost za to, da se spremenimo, je priložnost za razvoj. V luči teh trditev sprejmimo podatke in projekcije. Staranje prebivalstva bi bilo seveda ogrožajoče in težava, če ne bi pristali na številne in nujne spremembe.

Seveda pa leta 2060 starejši od 65 let, torej 30 odstotkov prebivalstva, najverjetneje ne bodo mogli živeti kot obrobna (proč od glavnega toka družbenega dogajanja in procesov odločanja) in vzdrževana skupina (odvisna od solidarnostne pogodbe med generacijami, od zmožnosti in prispevkov mlajših generacij). Zato je treba že danes spodbujati in omogočiti sodelovanje starejših v družbi tako v obliki smiselnega preživljanja prostega časa kot tudi izobraževanja, plačanega dela, prostovoljnega dela. ${ }^{3}$ Zanima nas torej dejavno staranje $v$ najširšem pomenu besede.

Še več, staranje prebivalstva je družbeno vprašanje, zato ga velja obravnavati na različnih ravneh in tudi razpršeno. Glede izobraževanja starejših odraslih in širše glede dejavnega staranja bi morali doseči:

- večjo osveščenost vseh skupin starejših, delodajalcev, svojcev, javnosti;

- večjo osveščenost in boljše znanje strokovnjakov vseh vrst in ustanov;

- visokošolske programe za vzgojo strokovnjakov na področju starosti in staranja;

- mrežno povezovanje vsebinsko sorodnih nevladnih organizacij in javnih ustanov na področju starejših;

- raznolike nosilce izobraževanja starejših odraslih;

- razvoj izobraževalnih programov za vse skupine starejših;

- resnično vseživljenjsko učenje in izobraževanje;

- večjo predanost javnih občil vprašanjem v povezavi z dejavnim staranjem prebivalstva;

- $\mathrm{k}$ dejavnemu staranju naravnane nacionalne in lokalne politike starosti in staranja.

Starejši ne bodo obrobna družbena skupina, temveč bodo ostali vključeni v glavni tok družbenega dogajanja takrat, ko bodo imeli tudi enakovreden dostop do različnih virov: dela, zdravja, kulture in izobraževanja. Tedaj bodo starejši tudi polno integrirani $\mathrm{v}$ družbo in ne bo nevarnosti, da bi bili, pogojno rečeno, »v breme«. Pogojno, kajti raziskave so pokazale, da starejši $\mathrm{v}$ poprečju postanejo prejemniki pomoči okoli 80 . leta starosti. Do takrat pa več dajejo drugim generacijam, kot prejemajo. ${ }^{4}$

V starajoči se družbi nujno potrebujemo novo družbeno pogodbo (Peyrefitte, 1996). Pri tem ne smemo pozabiti, da je starost zmeraj vprašanje (tihega) dogovora v družbi, je družbeni konstrukt. Sleherna družba tako na svoj način konstruira starost in jo konstruira zmeraj znova, ji na novo določa meje, določa starostna obdobja in določa smisel življenjskim obdobjem (Guilemard, 1986). Tako se zdi, da je zdajšnja kriza politike starosti in staranja bolj kriza nekega kulturnega modela organizacije starostnih obdobij in manj kriza javnih financ, kot nam pripovedujejo. Starejših je, kot kažejo navedeni podatki iz Ageing Report 2009 (slov. Poročilo o staranju 2009), več, razmerja med generacijami v starajoči se družbi se morajo spremeniti; starejši imajo svoje potrebe in pričakovanja in predvsem imajo zmožnosti, ki jih družba potrebuje. Zmožnosti, ki jih z izobraževanjem velja ohranjati, razvijati in integrirati v družbeni in ekonomski razvoj. 
Graf št. 1. Ravnovesje transferjev in podpore po starosti in po državah

(Vir: Martin Kholi, European University Institute)
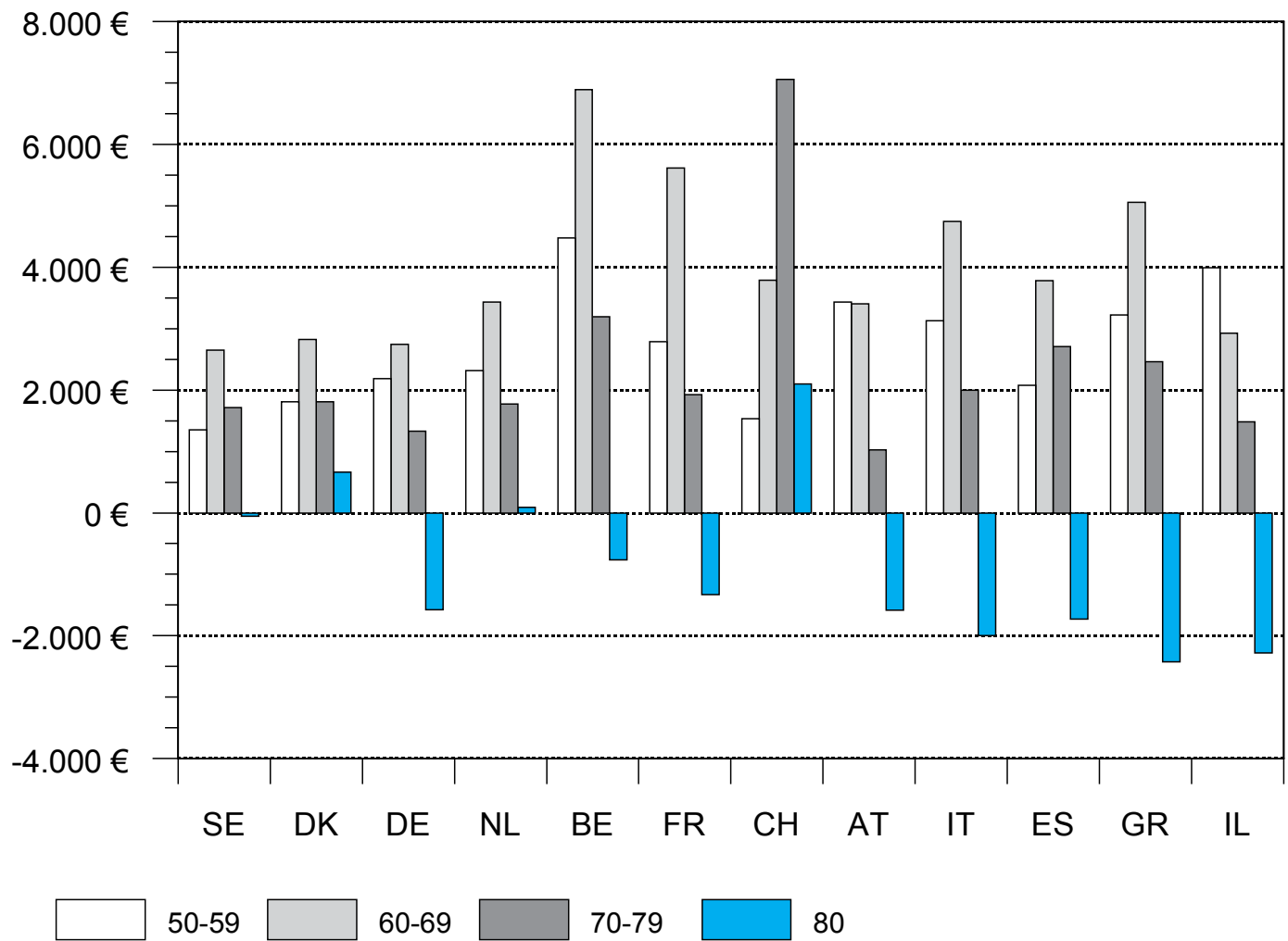

$50-59$

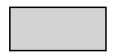

$60-69$

70-79

80

Od tega, koliko so starejši dejavni, premožni, izobraženi, je v starajoči se družbi odvisno blagostanje vseh. V Flash Eurobarometru, raziskavi o medgeneracijski solidarnosti, je kljub temu dejstvu 14 odstotkov Evropejcev v starosti od 15 let do 64 let odgovorilo, da so starejši v breme družbi, v Sloveniji kar 23 odstotkov. ${ }^{5}$ Kaj storiti, da opravimo to zmotno prepričanje? Izobraževanje, osveščanje imata pri tem pomembno vlogo.

Starejše potrebujemo, a potrebujemo jih še drugače, kot si predstavljajo evropski politiki.

Nekatera dejstva so torej neizpodbitna: Evropa se stara in $v$ tem vse pogosteje vidimo izjemno priložnost za njen razvoj. To dejstvo nas bo namreč prisililo, da začnemo upoštevati in uporabljati »mentalni kapital starejših «, spreminjajoč pri tem same sebe.
Nedvomno potrebujemo samozadostne, neodvisne starejše, a ne zgolj kot delavce, marveč kot sodelavce, kot prostovoljne delavce, kot učitelje, kot vodnike, kot sopotnike, kot člane družine. Potrebujemo njihov »mentalni kapital«, kot pravijo v še ne objavljeni študiji, ki jo je naročila vlada Velike Britanije januarja 2009. Gre za obsežno študijo o neformalnem izobraževanju, ki naj postane temelj za novo politiko izobraževanja starejših odraslih. Skovanka »mentalni kapital starejših « (kognitivni in emocionalni viri, prožnost in učinkovitost njihovega učenja) je namreč po mnenju avtorjev Poročila močno podcenjena. Kako ga prepoznati, kako ga bogatiti z uporabo? 


\section{SKUPINE STAREJŠIH IN IZOBRAŽEVANJE}

Pospešeno torej razmišljamo tudi o izobraževanju starejših, vseh skupin starejših: starejših delavcev, tistih pred upokojitvijo, tistih $\mathrm{v}$ tretjem življenjskem obdobju, oseb v četrtem življenjskem obdobju ali stanju odvisnosti. Pri tem velja opozoriti na naslednje: odkar smo stopili v čas postmoderne, se nekdaj tako pomembna in zaporedna življenjska obdobja (prvo, drugo, tretje, četrto) prekrivajo. To niso več kronološka časovna obdobja, so bolj stanja, v katerih se lahko znajdemo v življenju. Tako smo lahko večkrat v življenju v stanju tretjega življenjskega obdobja. Tedaj smo osvobojeni spon vsakdanjih delovnih urnikov in lahko iščemo vsebine za svoje življenje drugod, v kulturi, v izobraževanju. V stanju tretjega življenjskega obdobja so tako mlajši »osipniki«, mladi, ki med študijem »pavzirajo«, odrasli med dvema delovnima pogodbama, ljudje po upokojitvi. To stanje osvobojenosti od dela, značilno za tretje življenjsko obdobje, lahko kmalu zamenja stanje zaposlenosti, značilno za drugo življenjsko obdobje. Ljudje v pokoju tako tudi delajo.

V slovitih tridesetih letih, v času nenehne gospodarske rasti in polne zaposlenosti, te dinamike niso poznali. $\mathrm{V}$ tej dinamiki so se danes znašli, ali se bodo znašli, mnogi, tudi starejši, ki niso več preprosto $\mathrm{v}$ pokoju, marveč so $\mathrm{v}$ prehodnem obdobju, imenovanem »med delom, upokojitvijo in starostjo«. V obdobju, ki traja v poprečju 20 let pri moških in 24 let pri ženskah. ${ }^{6}$

V kategoriji od 56 do 64 let je danes v Sloveniji zaposlenih le nekaj več kot 32 odstotkov vseh oseb te starosti. Od tega nekaj več kot 10 odstotkov žensk. Drugi nastopijo pokoj. Pričakovanja oblikovalcev politike gredo $\mathrm{v}$ drugo smer. Hoteli bi, da bi starejši stopili v prehodno obdobje, da bi lahko delali dlje, da bi imeli nekatere ugodnosti, da bi prehajali od dela s skrajšanim delovnim urnikom - v katerem so nemalokrat mentorji mlajšim delavcem in $\mathrm{v}$ ta namen potrebujejo andragoško znanje - v stanje pokoja ali tretjega življenjskega obdobja in bi se kasneje ponovno vračali na trg dela. V tretjem življenjskem obdobju se starejši izobražujejo, vzdržujejo svojo zaposljivost in se občasno, tudi za dolgo, znova vračajo na delo - najpogosteje na delo, ne v službo - ali delajo prostovoljno, vse dokler ne nastopi četrto življenjsko obdobje, če nastopi, oziroma visoka starost, morebiti tudi potreba po dolgotrajni oskrbi.

$\mathrm{V}$ vsem tem dolgem času starejši potrebujejo izobraževanje. Kakšno naj bo to izobraževanje, kakšni naj bodo izobraževalni programi, je odvisno od današnjih ter prihodnjih potreb udeležencev, pa tudi od družbe. Načrtovalci programov naj pomislijo na to dejstvo. Programe narekujejo tudi motivi starejših udeležencev za izobraževanje. Velikokrat sledijo starim željam, ki jih niso mogli uresničiti. Pogosto se izkaže, da se za izobraževanje odločijo celo na podlagi neuresničenih želja svojih prednikov. »Moj ded je umrl, ko mi je bilo dve leti. Nisem ga poznala, a vem, da je želel študirati psihologijo, pa ni mogel. Tudi jaz nisem mogla. Zato sem se zdaj odločila za psihologijo.« Ali pa: »Vse življenje sem si želel, da bi lahko slikal. Zdaj se mi je ta želja uresničila.« Takšne so pogoste izjave starejših udeležencev izobraževanja. ${ }^{7} \mathrm{Na}$ to, kakšni bodo programi, vpliva tudi naše poznavanje generacijskih značilnosti udeležencev izobraževanja; njihovih skupnih generacijskih značilnosti na področju dela, kulture, dejavnega državljanstva, zavedanja skupnosti, na področju izkušenj z izobraževanjem in usposabljanjem. Analiza posameznih generacijskih značilnosti je namreč pomembna za razumevanje motivov, potreb, zanimanj, želja starejših in udeležbe starejših v izobraževanju. Potrebna je tudi za razumevanje njihovega učenja (Field in drugi, 2008). Izobraževalci, ki pripravljajo izobraževalne programe za starejše, vedo, da ni mogoče uporabiti že narejenih programov in jih »prilagoditi«. Programi nastajajo iz dobrega poznavanja starej- 
ših in družbe. Pri programiranju izobraževanja se moramo otresti vrste stereotipov o starejših in starosti.

$\mathrm{V}$ evropskem projektu IANUS prav zdaj pripravljamo Evropske smernice za izobraževanje starejših odraslih. ${ }^{8}$ Prva različica smernic, ki smo jih prispevali številni partnerji v projektu, je bila navaden skupek stereotipov o starejših ljudeh in o njihovem učenju: starejši so hendikepirani, so slabega zdravja, slabo slišijo, slabo vidijo, boli jih hrbtenica, zgubljajo spomin, ne zmorejo dolgotrajnega napora, spreminjajo se njihove nevrološke zmožnosti, se slabše učijo. Ali pa tudi: starejši so dobri, mili, pripravljeni pomagati. Stereotipi torej! Izobraževalci starejših odraslih se moramo stereotipov otresti. To se bo zgodilo šele takrat, ko bomo starejše odrasle dobro poznali, $v$ nasprotnem primeru bomo stereotipe nevede utrjevali. ${ }^{9}$

\section{VREDNOTE, NOSILCI IN OBLIKE IZOBRAŽEVANJA STAREJŠIH ODRASLIH}

Po izobraževanju starejših odraslih smo v Sloveniji v evropskem vrhu. Glede tega, pravijo raziskovalci Eurostata, bi se moral »evropski sever učiti od evropskega juga«, od Slovenije in Avstrije. Tako bi se moralo preučevanje evropskih razsežnosti izobraževanja starejših pravzaprav začeti v Avstriji ali Sloveniji, kjer danes srečujemo različne nosilce tega izobraževanja. Devetintrideset univerz za tretje življenjsko obdobje z 21.000 študenti, Inštitut Antona Trstenjaka, Gerontološko društvo Slovenije, Andragoški center Slovenije in mreža študijskih krožkov, društva upokojencev, stanovska društva, ljudske univerze, knjižnice, muzeji, centri za socialno delo, domovi starejših in drugi, denimo Gospodarska zbornica Slovenije, Združenje delodajalcev, večja podjetja ipd. Avstrija podpira

Po izobraževanju
starejših odraslih
smo v Sloveniji v
evropskem vrhu.
predvsem formalno izobraževanje, do katerega imajo dostop starejši, Slovenija predvsem neformalno izobraževanje, ki je nastalo in se je razvijalo predvsem v civilni družbi. Potrebovali pa bi obe vrsti izobraževanja starejših odraslih.

Za našo obravnavo izobraževanja starejših je morda pomembno predvsem to, da preučimo temeljne vrednote, ki narekujejo izobraževanje starejših v posameznih kulturnih in družbenih okoljih.

V ZDA, kjer se je izobraževanje starejših razvilo razmeroma zgodaj, gre $\mathrm{v}$ izobraževanju starejših odraslih predvsem za prijetno porabo prostega časa in rekreacijo.

V Veliki Britaniji si je izobraževanje starejših odraslih prisvojilo značilnosti in vrednote že prej razvitega skupnostnega izobraževanja. $\mathrm{V}$ francoskem konceptu prevladujejo načelo kolektivnega osvobajanja starejših, načelo poprave njihovega družbenega položaja pa tudi preporod starejšega človeka.

Naj zdaj sklenem ta del razprave s spoznanjem, ki ga izobraževalci ne smemo spustiti izpred oči: starejši odrasli niso homogena skupina. ${ }^{10}$ Niso homogena skupina delavcev, potrošnikov, niso homogena skupina volilcev, niso homogena skupina učencev. Starejši odrasli, skupine starejših odraslih so različnih let, a to dejstvo nam silno malo pove o tem, kakšen naj bo izobraževalni program zanje, kaj si želijo z izobraževanjem doseči in kako naj poteka izobraževanje. ${ }^{11}$ Pač pa bo na vsebino, cilje in metode izobraževanja močno vplivalo to, kako je tekla in kako teče njihova življenjska pot, kakšne so njihove generacijske značilnosti, kateri starostni kohorti pripadajo. ${ }^{12}$ Vplivali bodo tudi njihov zdajšnji položaj v družbi, katerega spola so, njihovo zdravstveno stanje, njihov položaj v družini, stopnja njihovega plačanega ali prostovoljnega sodelovanja $v$ družbi. Vse to bo pomembno, le leta ne, le starost ne. 
$\mathrm{V}$ nemškem konceptu zaznamo predvsem izobraževanje starejših kot socialno storitev, kot vzpostavitev družbene pravičnosti do generacij, ki so v mogočem prispevale $\mathrm{k}$ obnovi države.

Spet drugod gre za načelo enakomerne porazdelitve storitev med različne starostne skupine. Med te storitve sodi tudi izobraževanje.

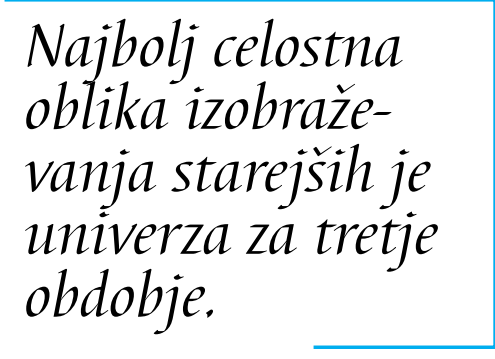

V Avstriji se rojeva načelo povezovanja med rodovi mladih in starih itn.

V razvoju izobraževanja starejših odraslih v Sloveniji zagovarjamo nekatere osnovne vrednote, ki so se oblikovale tudi kot temeljna načela izobraževanja za starejše odrasle na Univerzi za tretje življenjsko obdobje: (1) načelo pozitivnega odnosa do starosti in staranja; (2) načelo vseživljenjskosti izobraževanja; (3) načelo navzočnosti kulture $\mathrm{v}$ izobraževanju; (4) načelo povezave izobraževanja starejših z lokalnim razvojem; (5) načelo gradnje osebne družbene vrednosti in integracije v družbo.

Na Inštitutu Antona Trstenjaka srečamo še nekatera druga načela, kot so načelo vzajemnosti generacij in kakovostne starosti.

Problematiko izobraževanja starejših odraslih ali ljudi v poznejših letih življenja $v$ tesni povezavi s problematiko starosti in staranja smo v Sloveniji začeli preučevati že pred četrt stoletja med prvimi v Evropi, ob nastanku Slovenske univerze za tretje življenjsko obdobje. To problematiko danes preučujemo tudi na Filozofski fakulteti v Ljubljani, predvsem na oddelku za pedagogiko in andragogiko, v Andragoškem centru Slovenije in drugod. Samo problematiko starosti in staranja so že zgodaj zavzeto in $\mathrm{z}$ veliko uspeha preučevali v Gerontološkem društvu Slovenije, na Inštitutu za gerontologijo in geriatrijo v Ljubljani, kjer smo tudi sami pri profesorju Bojanu Acettu in profesorju Bogdanu Leskovicu našli prve spodbude za svoje izobraževalno delo, in drugod. Danes ima osrednje mesto na tem podro- čju Inštitut Antona Trstenjaka s profesorjem Jožetom Ramovšem. Tudi Zveza društev upokojencev preučuje posamezne vidike starosti in staranja.

\section{UNIVERZA ZA TRETJE ŽIVLJENJ- SKO OBDOBJE KOT OBLIKA IN MODEL NEFORMALNEGA IZO- BRAŽEVANJA LJUDI V POZNEJ- ŠIH LETIH ŽIVLJENJA}

Ena najbolj celostnih oblik izobraževanja starejših odraslih je univerza za tretje življenjsko obdobje. Nastala je v Franciji leta 1973, kmalu po tistem, ko se je francoska politika starosti in staranja iz socialno varstvene politike prevesila v politiko načina življenja starejših. Takrat prosti čas postane pomembno področje in takrat se pojavijo klubi upokojencev, klubi tretjega časa, univerze za tretje življenjsko obdobje.

Prva univerza je nastala v Toulousu, nadaljnjih 63 še v istem letu. To je bil čas socialistične vlade, na čelu države takrat ni bil poslovnež, marveč humanistično naravnan mislec in izobraževanje starejših odraslih je tako postalo ena od programskih tez takratne Miterrandove socialistične vlade.

Univerzo za tretje življenjsko obdobje smo snovali v Sloveniji deset let kasneje, leta 1984, a še vedno dosti pred nekaterimi drugimi evropskimi državami. Model te univerze smo začeli snovati na skromnih temeljih: na nekaj podatkih in vtisih iz pogovora $\mathrm{z}$ ustanoviteljem, profesorjem mednarodnega prava Pierrom Velassom s Fakultete za družbene vede v Toulousu in na podlagi poznavanja kanadske literature in primerov izobraževanja starejših, predvsem pa na opazovanju lastne inducirane prakse. Literature o tovrstnem izobraževanju je bilo takrat malo. $\mathrm{V}$ tem je bila nedvomno prednost, da smo lahko zgradili izvirno svoj, celostni model univerze za tretje življenjsko obdobje. Prednosti slovenske univerze za tretje življenjsko obdobje so naslednje. 
Poslanstvo slovenske Univerze za tretje življenjsko obdobje se deloma spreminja skozi čas, preprosto zato, ker se spreminja družba. V čem je današnje poslanstvo slovenske Univerze za tretje življenjsko obdobje? V izboljševanju življenja starejših v odnosu do vseh generacij ob pomoči kulture in izobraževanja. To dosegamo z raziskovanjem, javno kampanjo, izobraževanjem za osebnostno rast, plačano delo in prostovoljno delo in v zadnjem času $\mathrm{z}$ integriranim svetovanjem za dejavno staranje. Njene prednosti so $v$ izvirnem, kulturno in družbeno našem, slovenskem celostnem konceptu in modelu Univerze za tretje življenjsko obdobje, ki je zrasel iz našega kulturnega okolja, iz naših ljudi, iz naših raziskav in prakse, ki smo jo inducirali pred 25 leti.

- Slovensko Univerzo smo ustanovili in domislili andragogi, zato smo njen pomen zagledali drugače kot $\mathrm{v}$ drugih evropskih državah.

- Univerzo smo ustanovili kot nevladno organizacijo, ki je svobodnejša od akademskega okolja.

- Zgodaj smo uvedli izobraževanje za življenje, takšno izobraževanje pa je par excellence neformalno, kajti le tako je lahko blizu življenju. Pri tem gre manj za transmisijo znanja, zato pa toliko bolj za konstruiranje novega znanja skupaj z udeleženci.

- Študijske krožke Univerze in njihovo učenje smo takoj povezali z lokalnim okoljem in delovanjem starejših ljudi v lokalnem okolju. Tako so se študenti lahko neprestano preverjali v očeh javnosti.

- Vedeli smo, da vsakdo potrebuje primarne družbene skupine (kjer vladajo bližnji odnosi in čustvene vezi) in smo jih na Univerzi tudi omogočili.

- Uvedli smo izobraževanje, osredotočeno na osebne in družbene potrebe.

- Izoblikovali smo izobraževanje starejših kot način življenja.

- Izobraževanje starejših odraslih spremljamo z močno kampanjo za prepričevanje javnosti.

$\mathrm{Pa}$ vendar je naša bistvena prednost drugod.

- V tem, da spremljamo družbene smernice in se jim prilagajamo v izobraževalnih programih.

- V tem, da nenehno povezujemo prakso izobraževanja starejših odraslih z raziskovanjem.
- V tem, da smo dobro opredelili koncepte izobraževanja starejših, ki smo jih povezali $\mathrm{v}$ lastno teorijo.

Naših raziskav izobraževanja starejših odraslih je veliko, četudi so potekale na omejenem, majhnem vzorcu. Te raziskave so nam pomagale prakso voditi v smeri, ki so jo nakazali starejši udeleženci izobraževanja. Nastalo je veliko majhnih rešitev, ki so nazadnje prinesle dobro razvito izobraževanje starejših, in tudi družbene spremembe. Danes se izobraževanju starejših odraslih v Sloveniji ne čudimo več. Zvečine smo prepričani, da je to izobraževanje potrebno in koristno za starejše (Novšak, 2002).

V slovenskem prostoru imamo težave uvideti:

- da je izobraževanje potrebno prav vsem (starejšim delavcem, ljudem pred upokojitvijo, ljudem v tretjem življenjskem obdobju pa tudi tistim v visoki starosti) oziroma da je pomembna kontinuiteta izobraževanja starejših;

- da je znanje starejših in drugih generacij potrebno in da potrebujemo več medgeneracijskega učenja;

- da se znanje starejših sme in mora pretočiti v organizirano sodelovanje starejših v družbi, plačano delo in profesionalno prostovoljstvo, torej, v dejavno staranje;

- da potrebujemo boljše sodelovanje med nevladnimi in javnimi organizacijami;

- da minimalna javna sredstva za izobraževanje starejših odraslih ne omogočajo, da bi se bolj posvetili razvoju in mreženju vsebinsko sorodnih organizacij, čeprav bi bilo to vredno in potrebno; 
- da potrebujemo celostno politiko izobraževanja starejših tako na lokalni kot tudi na nacionalni ravni.

\section{NEKAJ SPOZNANJ NAMESTO ZAKLJUČKA}

Družba se stara, toda staranje prebivalstva je izjemna priložnost za spremembe in razvoj in iskanje nove družbene pogodbe med vsemi generacijami.

Za integriranost $v$ družbo starejši potrebujejo dostop do virov: dela, zdravja, kulture, izobraževanja in drugih pomembnih virov

$V$ starajoči se družbi naj starejši in mladi enakovredno sodelujejo $v$ družbi. To je trd oreh, ki ga morajo streti generacije $\mathrm{v}$ sredini, tiste, ki imajo škarje in platno v svojih rokah. $\mathrm{Ob}$ tem se bo seveda spremenil tudi položaj teh generacij. ${ }^{13}$

Družba znanja potrebuje kognitivne vire. Kaj je njen kapital, kaj je njena konkurenčna prednost? To so kognitivni viri. To je znanje, to so spretnosti, to je inovativnost, ki se gradi iz vsega, kar smo izkusili mi in kar so izkusili drugi, gradi se iz povezanosti generacij.

Esther Duflo, mlada profesorica, ki predava razvojno ekonomijo na Massachusetts Institute of Technology in je soustanoviteljica Jameel Poverty Action Lab - laboratorija za preučevanje razvoja in revščine - je v svojem uvodnem predavanju o revščini na Collège de France (2009) za razumevanje začaranega kroga inovacij navedla primer neke afriške pokrajine: na enem delu pokrajine je zemlja zelena, kajti tam so ljudje med seboj povezani, se med seboj pogovarjajo, izkušnje krožijo, nastajajo nove izkušnje, nova spoznanja, delo in življenje sta tako drugačna. Boljša. Revščine ni! V tem delu pokrajine niso prejeli več mednarodne pomoči, le ljudje so se tokrat s pomočjo zavzetih znanstvenikov med seboj povezali. Tako je tudi v izobraževanju starejših odraslih. Najverjetneje ne bo nastalo in se širilo samo zase. Potrebovali bomo več raziskovanja, več izobraževanja voditeljev in mentor- jev, več struktur, več organizacij, več socialnih mrež, več socialnega kapitala, v katerega se bo ujel človeški kapital starejših in mlajših, se tam množil in rasel. Brez tega bomo v starajoči se družbi revni in zaostali. Tu pa so pomembni predanost in prizadevanja nas vseh: strokovnjakov, izobraževalcev, politikov na vseh ravneh: lokalni, nacionalni, evropski, in predvsem so potrebna prizadevanja starejših samih.

\section{LITERATURA IN VIRI}

Anon (1989). Izobraževanje starejših v Franciji. Poročilo za četrto mednarodno konferenco o izobraževanju odraslih. Pariz: UNESCO, 1985. Ljubljana: UTŽO, Andragoško društvo Slovenije, 1989.

Anon (2006). Learning in Later Life, A Public Spending Challenge. Niace, VB.

Anon (2009). »Ageing Communication: a renewed strategy for tackling Europe's demographic challenge «. Rapid Press Realease Europa.

Anon (2009). Ageing Report 2009.

Anon (2009). »Interegenerational Solidarity«. Flash Eurobarometer 269.

Durandal, J-Ph. V. (2003). Le Pouvoir gris. Sociologie des groupes de pression de retraités. Pariz: PUF.

Field, J. in drugi (2008). Learning Lives. (V tisku.)

Findeisen, D. (1995). Jezikovna vzgoja starejših odraslih na Univerzi za tretje življenjsko obdobje. Ljubljana: FF.

Findeisen, D. (1999). Izobraževanje odraslih za življenje v njihovih poznejših letih, Ljubljana: FF.

Gielle, J. and Elder, G. (1998) Methods of Life Course Research: Qualitative and quantitative approaches. Sage. Thousand Island. KA.

Guillemard, A.-M. (1986) Le déclin du social. Pariz: PUF.

Jelenc Krašovec, S., Kump, S. »Širjenje socialnih mrež starejših ljudi s pomočjo izobraževanja«. Socialno delo, 2006. L. 45, št. 3/5, 143-151.

Kneževič, S. (2007). Izobraževanje starejših na Univerzi za tretje življenjsko obdobje za osebnostno rast in njihovo sodelovanje $v$ družbi, diplomsko delo, Ljubljana: FF.

Krajnc, A. in drugi: (1992) Kako smo snovali Slovensko univerzo za tretje življenjsko obdobje, Ljubljana: UTŽO.

Kroener, S. in drugi (2008). Demographic future of Europe.

Novšak, J. (2002). Izobraževalne aspiracije starejših odraslih v Posavski regiji. Diplomsko delo, FF, Ljubljana. 
Peyrefitte,A. (1995) La société de cofiance, Paris: Odile Jacob.

Ramovš, J. (2008). Evropska in slovenska strategija starajoče se družbe in medgeneracijski menedžment staranja na delovnem mestu. Ljubljana: Kapitalska družba.

Roberts, K. (1981). Leisure, London: Longman.

Rojek, C. (2000). Leisure and Culture. New York: Palgrave Macmillan.

Stebbins, R. Vincent, J. A. (2005) »Understanding Generations: Political economy and culture in an ageing societ «. British Journal of Sociology, 56, 4, 579-599.

Zalokar, M. (2000). Vpliv izobraževalne biografije na izobraževanje starejših odraslih. Diplomsko delo. Ljubljana: FF.

Weber, M. (1978) Die protestantische Ethik, Kritiken und Antikritiken, Gütersloher Verlagshaus Gerd, Mohn.

1 Generacije mladih nimajo marsičesa, kar so imele generacije pred njimi, imajo pa veliko več možnosti izobraževanja (Field, 2008).

2 Ana Krajnc na konferenci Medgeneracijska solidarnost za družbe sožitja in socialne povezanosti, Brdo, Slovenija, od 27. do 29. aprila 2008.

3 Dolgo je veljalo, da je prosti čas neizpodbitni dosežek sodobne družbe, a prosti čas ni zgolj dosežek in dobrina, ni zgolj pozitiven pojav. Prosti čas lahko vodiv jemanje mamil, alkoholizem, nezadovoljstvo, bolezen. To velja tudi za prosti čas upokojencev: lahko postane dosežek ali pa vir degradacije njih samih in družbe.

4 Martin Kholi: Rethinking intergenerational solidarity in ageing societies, Conference on Intergenerational Solidarity for Cohesive and Sustainable Societies. Brdo, Slovenija. Od 27 do 29. aprila 2008.

5 Flash Eurobarometer 269 on Intergenerational Solidarity.

6 Kako bodo v tem času zadovoljevali svoje potrebe, je odvisno od njih samih, njihovega partnerja, od njihove družine, lokalnega okolja in lokalnih politikov, od nacionalnega okolja in politikov.

7 Monika Zalokar: Vpliv izobraževalne biografije na izobraževanje starejših odraslih. Diplomsko delo. FF, Ljubljana, 2000.

8 IANUS http://www.ianusllp.com/

$9 \mathrm{Ob}$ zagovoru magistrskega dela je mentorica zatrjevala, da je za njene starejše študente opis umetniških stvaritev primerna metoda, metoda širše razlage umetniških stvaritev $z$ vidika referenčnih ved pa ne. In kdo so bili njeni starejši študenti? Upokojeni zdravniki, pravniki itn.
10 Zanimivo je, da smo pripadnike obrobnih družbenih skupin zmeraj pripravljeni obravnavati kot homogene družbene skupine.

11 Srečujemo programe, kot so »Internet za starejše $i d r$. Razumem, da obstaja »telovadba za starejše», kajti telesna zmogljivost je $v$ različnih življenjskih obdobjih različna, toda internet? Internet je zmeraj isti za vse starosti, le da ga vsak od nas uporablja v različne namene. 12 Elder (1975) poudarja, da so razlike med kohortami največje, kadar smo izpostavljeni hitrim spremembam. Kohorte so tedaj povezane tako, da je "povezano njihovo socialno življenje«.

13 Ko smo nedavno poskusno znotraj projekta AESAEC (sofinancira ga evropska komisija) preverjali pri univerzitetno izobraženih starejših, kakšno je njihovo poznavanje vloge evropskih institucij, smo denimo spoznali, da je to razmeroma slabo. Evropske institucije so oddaljeni centri moči. Zato v projektu AESAEC poskušamo starejše pripraviti $k$ temu, da bodo spoznali te institucije, jim približati zgodovino Evrope, omogočiti starejšim udeležencem, da se naučijo snovati in voditi evropske projekte. Vsekakor želimo, da spoznajo delo evropskih institucij, da s svojimi spoznanji vplivajo na politike, ki nastajajo v teh inštitucijah in se od tam širijo v države članice. 